\title{
Selection of Indigenous Rhizobacterial Isolates Capable of Inducing Resistance of Chili Against Colletotrichum gloeosporioides
}

\author{
F Fatimah ${ }^{1}$ \\ Faculty of Agriculture, Tamansiswa University, Padang, West Sumatera, Indonesia ${ }^{1}$ \\ \{ fatimah.kasim16@gmail.com $\left.{ }^{1}\right\}$
}

\begin{abstract}
Anthracnose, a disease caused by Colletotrichum gloeosporioides which affects chili, is difficult to control. Biological control with indigenous rhizobacteria (RB) can be a solution as the bacteria are conditioned to their natural habitat.The advantage of using indigenous rhizobacteria is that it is easy to adapt to the target plant and multi mechanisms, i.e. not only to control plant diseases but also to enhance the growth and yield of chili. The aim of this research was to determine the isolates of indigenous RB capable of enhancing the resistance of chili crops against anthracnose disease. Indigenous RB isolates were obtained from healthy rhizosphere chili in endemic areas of anthracnose disease in West Sumatera. Sampling was done by using a purposive method, based on geographical conditions, namely: 1 . Lowland ( $<400 \mathrm{~m}$ above sea level (asl), Padang City, 2. Medium land (400-700 asl), Lima Puluh Kota District, 3. Highland (> 900 asl),Agam district.This research consisted of two stages, 1 . The selection of 169 isolates of indigenous RB for their capability to enhance the growth of chili seedlings and 2.The testing of selected isolates of indigenous RB in inducing the resistance of chili against anthracnose disease. The parameters observed were: time and percentage of germination, seedling height, number of seedling leaves, root length of seedlings, wet seedling weight, dry seedling weight, incubation period, attack intensity, percentage of infected fruits, plant height, number of fruits per plant and fruit weight per plant. The resultsshowedthat 19 the isolates of indigenous RB were capable of stimulating the growth of chili seedlings, which consisted of 7 isolates of indigenous RB from Padang city, 7 isolates of indigenous RB from Agam district and 5 isolates of RB from Lima Puluh Kota District. Three RB isolates were capable of controlling anthracnose disease, namely isolates of RB B1.37 and P1.31 with $0 \%$ attack intensity, and B2.11 with $27.8 \%$ anthracnose disease attack intensity.
\end{abstract}

Keywords: Isolates, rhizobacteria, Indigenous, Colletotrichum gloeosporioides

\section{Introduction}

An anthracnose disease caused by Colletotrichum gloeosporioides can be found in all types of chilli crops planted in the lowlands and highlands[1]. This pathogen is difficult to control 
because it can be transmitted through seeds (seed-borne disease), infecting hyphae is shielded within the plant's cuticle, and has high genetic diversity [2].

The recommended controls are using resistant varieties, practicing crop rotations, and discarding the remains of chili plants after harvest. Chemical control was done by using fungicides such as triazole and pyrimidine, but the results are not maximized. One of the alternative controls is the use of biological agents from the rhizobacteria group [3] and [4]. Biological control using indigenous rhizobacteria is more effective when it is introduced to related plants because of its higher compatibility and adaptability. Mechanisms of biological agents are antibiosis, parasitism, competition, and induction of resistance [5] and [6]. The use of biological agents, in addition to suppressing the development of plant diseases, can also increase the growth and yield of plants. Several types of bacteria, as biological agents, are known as plant growth-promoting Rhizobacteria (PGPR).

Fatimah[7] reported that the introduction of indigenous rhizobacteria in chili seeds increased plant growth and was detected to produce IAA-producing hormones but not in controls. PGPR treatment on chili seeds and seedlings could increase plant height, leaf number, and yield. Several types of rhizo bacteria are able to induce plant resistance to pathogens such as induction of tomato plant resistance to wilt disease (Fusarium oxysporum) using endophytic bacteria [8]. The results of Saleem [4] showed that indigenous rhizo bakteria from the rhizosphere of chili plants could induce chili resistance against bacterial wilt disease (Ralstonia solanacearum). While the use of rhizobacteria for anthracnose disease control among others is: the application of biocontrol agent Bacillus subtilis capable of inhibiting the growth of $C$. gloeosporioidesas causes of anthracnose disease in strawberry, apple, pear and tomato plants in vitro [9]. Related term of dry weight the Bacillus subtilus inhibited Colletotrichum gloeosporoides up to $100 \%$ in dual liquid culture [10]

The purpose of this study isto obtain isolates of indigenous rhizo bacteria from a healthy chili rhizosphere able to stimulate the growth of chili seedlings and induce chilli's resistance against $C$. gloeosporioides.

\section{Material And Methods}

The research consisted of 2 stages, 1) Selection of indigenous rhizobacteria isolates capable of increasing the growth of chili seedlings. In this study, the treatments were arranged in a Completely Randomized Design (CRD) consisting of 169 treatments and 10 replications. The treatments were rhizobacterial isolates introduced to chili seeds. Data were not analyzed. 2). Selection of indigenous rhizo bacterial isolates to induce chili's resistance against $C$. Gloeospoiroides as a cause of anthracnose disease in chili plants. This experiment was conducted at Horticulture and Food Crops Plant Protection Agency, Padang, West Sumatra Province. The experimental design used was CRD, which consisted of 24 treatments and 3 replications. The treatments were selected rhizobacterial isolates as the result from stage 1 . The parameters observed were anthracnose disease development, growth, and yield of chili. Data on the number and weight of healthy chilies were analyzed by using the F test and followed by Duncans Multiple Range Tests (DMRT) as presented in the table. 


\subsection{Working Procedure}

\subsubsection{The exploration of rhizobacteria from the rhizosphere of healthy chili plants.}

The exploration of rhizobacteria from rhizo sphere of healthy chili plants in endemic areas of anthracnose disease was done by using purposive random sampling method with the following criteria: chili production centers were located at different altitudes (low, medium and high), the areas were endemic anthracnose disease and planted areas were $250 \mathrm{~m}^{2}$ minimum.

\subsection{Propagation of indigenous rhizobacterial isolates.}

Rhizobacterial isolates were propagated in NA medium (nutrient agar). 48-hour pure cultures were suspended in sterile distilled water until they reached a population density of $10^{8}$ cells/ml based on the Me Farland solution [11].

\subsection{Preparation of planting media}

Planting media used were a mixture of soil and manure with a ratio of $2: 1(\mathrm{v} / \mathrm{v})$ and then sterilized by tyndalisation( 1 hour heating at 1000C) and incubated for 24 hours and repeated 3 times. Subsequently, the media were placed in polybags with a diameter of $22 \mathrm{~cm}(8 \mathrm{~kg}$ of media per polybag)

\subsection{Introduction of indigenous rhizobacterial isolates on chili seedlings}

Indigenousrhizobacterialisolates used were the result of rhizobacteria from stage 1. Fourweek-old seedlings were transferred to polybags then splashed with $10 \mathrm{ml}$ of indigenous rhizobacterial suspension.

\subsection{Maintenance}

Maintenance included: fertilizing, weeding, watering and pest control. Chilli plants were fertilized with artificial fertilizers, Urea $1.2 \mathrm{~g} /$ polybag (300 kg/ha), SP36 $0.8 \mathrm{~g} /$ polybag (200 $\mathrm{kg} / \mathrm{ha}$ ) and $\mathrm{KCl} 0.8 \mathrm{~g} /$ polybag (200kg/ha).Fertilizers were given 2 times; 1 ) a half of Urea, all SP36 and $\mathrm{KCl}$ were given an entire planting time 2). The other half of Urea was given 35 days after planting [12]. Weeding was done mechanically. When it did not rain the plants were watered 2 times a day. Pests were controlled mechanically.

\subsection{Selection of indigenous rhizobacterial isolates capable of inducing chili's resistance against Colletotrichum gloeosporioidesas a cause of anthracnose disease in chili}

Propagation of Colletotrichum gloeosporioides. C. Gloeosporioides isolates used were obtained from the collection of Biotechnology Laboratory Department of Agricultural Faculty Andalas University, then they were rejuvenated on Potato Dextrose Agar medium by using Fungal mat with $1 / 2 \mathrm{~cm} 2$ and incubated for 12 days and reproduced on Potato Dextrose Agar medium.

Inoculation of Colletotrichum gloeosporioides. Chili plants were inoculated on fruits one month after flowering by using the technique of[13]. Inoculation of C.gloeosporioides was done by using a syringe. Ten chili fruits having uniform age and fruit size were inoculated with 
conidia suspension $\left(10^{5} \mathrm{sel} / \mathrm{ml}\right.$ density) by injecting $0.1 \mathrm{ml}$, then the fruits were wrapped with wet cotton. To keep the plant's moisture they were encased with clear plastic for 3 days.

\section{Result And Discussion}

\subsection{Selection of indigenous rhizobacterial isolates for growth of chili seedlings}

The ability of indigenous rhizobacterial isolates to stimulate the growth of chili seedlings varied among isolates. Nineteen indigenous rhizobacterial isolates ( 7 from lowland, 6 from medium plain and 6 from highland) showed the ability to increase the height of chili seedlings $(10.30-11.90 \mathrm{~cm})$ with the effectiveness of 45.0-67.6\% compared to control $(6.7 \mathrm{~cm})($ Table 1$)$. The ability of some other rhizobacterial isolates was the same as controls while some others were lower than controls. Rhizobacterial isolates able to cause the highest increase in height of seedlings were P2.11 $(11.90 \mathrm{~cm}), \mathrm{Y} 1.15(11.80 \mathrm{~cm}), \mathrm{Y} 1.21(11.78 \mathrm{~cm})$, and B1.37 $(11.77 \mathrm{~cm})$. In this case, it was seen that there was no effect of different altitutes as sources of rhizobacterial isolates on the increase of the height of chili seedlings.

Table 1. Growth of chilli seedlings introduced by rhizobacterial isolates from endemic areas of anthracnose diseases with different altitutes.

\begin{tabular}{|c|c|c|c|c|c|c|c|c|c|c|c|c|c|c|c|c|}
\hline \multirow{3}{*}{ No } & \multicolumn{2}{|c|}{ Isolate } & \multicolumn{4}{|c|}{ Length of germinating } & \multicolumn{10}{|c|}{ Seedling } \\
\hline & \multirow[t]{2}{*}{ Code } & \multirow[t]{2}{*}{ Altitute } & \multirow[t]{2}{*}{ day } & \multirow{2}{*}{$\begin{array}{l}\text { Effec } \\
\text { tive } \\
\text { ness }\end{array}$} & \multirow[t]{2}{*}{$\%$} & \multirow{2}{*}{$\begin{array}{l}\text { Effec } \\
\text { tive } \\
\text { ness }\end{array}$} & \multicolumn{2}{|c|}{ Height } & \multicolumn{2}{|c|}{$\begin{array}{c}\text { Number } \\
\text { leaves }\end{array}$} & \multicolumn{2}{|c|}{ Root length } & \multicolumn{2}{|c|}{ Wet weight } & \multicolumn{2}{|c|}{ Dry weight } \\
\hline & & & & & & & $\mathrm{Cm}$ & Eftv & $\begin{array}{c}\text { leafl } \\
\text { et }\end{array}$ & Eftv & $\mathrm{cm}$ & Eftv & $\mathrm{Gr}$ & Eftv & Gr & Eftv \\
\hline 1 & $\mathrm{P} 2.11$ & LL & 5,1 & 23,9 & 100 & 0,0 & 11,90 & 67,6 & 7,9 & 92,0 & 21,6 & 95,0 & 1,35 & 264,8 & 0,13 & 225,0 \\
\hline 2 & $\begin{array}{r}\mathrm{Y} 1.15 \\
\mathrm{k} \\
\end{array}$ & ML & 6,2 & 7,4 & 100 & 0,0 & 11,80 & 66,2 & 7,8 & 90,0 & 17,0 & 53,0 & 1,50 & 305,4 & 0,16 & 300.0 \\
\hline 3 & Y1.21 & ML & 6,5 & 2,9 & 100 & 0,0 & 11,78 & 65,9 & 7,3 & 78,0 & 16,9 & 52,0 & 0,67 & 81,0 & 0,07 & 75,0 \\
\hline 4 & B1.37 & $\mathrm{HL}$ & 6,5 & 2,9 & 100 & 0,0 & 11,77 & 65,7 & 6,3 & 54,0 & 17,0 & 53,0 & 0,60 & 62,0 & 0,08 & 100,0 \\
\hline 5 & B2.20 & HL & 6,2 & 7,4 & 100 & 0,0 & 11,23 & 58,2 & 7,5 & 83,0 & 17,4 & 57,0 & 0.71 & 92,0 & 0,10 & 150,0 \\
\hline 6 & B2.11 & DT & 6,0 & 10,4 & 100 & 0,0 & 11,22 & 58,0 & 7,4 & 80,0 & 17,3 & 56,0 & 0,76 & 105,4 & 0,10 & 150,0 \\
\hline 7 & Y1.6 & $\mathrm{NL}$ & 6,0 & 10,4 & 100 & 0,0 & 11,21 & 57,8 & 7,1 & 73,0 & 17,1 & 54,0 & 1,39 & 275,7 & 0,09 & 125,0 \\
\hline 8 & B2.9 & HL & 6,5 & 2,9 & 100 & 0,0 & 10,93 & 53,9 & 6,6 & 61,0 & 17,1 & 54,0 & 0,63 & 71,0 & 0,06 & 50,0 \\
\hline 9 & B1.29 & $\mathrm{HL}$ & 6,5 & 2,9 & 100 & 0.0 & 10,90 & 53,5 & 6,4 & 56,0 & 17,3 & 56,0 & 0,67 & 81,0 & 0,09 & 125,0 \\
\hline 10 & P2.3 & LL & 5,2 & 22,3 & 90 & $-10,0$ & 10,70 & 50,7 & 7,1 & 73,0 & 21,0 & 89,0 & 0,78 & 110,8 & 0,07 & 75,0 \\
\hline 11 & $\mathrm{Y} 2.4 \mathrm{a}$ & ML & 6,6 & 1,4 & 100 & 0,0 & 10,60 & 49,3 & 6,2 & 51,0 & 17,8 & 60,0 & 0,57 & 54,0 & 0,06 & 50,0 \\
\hline 12 & $\mathrm{P} 1.31$ & LL & 5,9 & 11,9 & 100 & 0,0 & 10,55 & 48,6 & 7,0 & 71,0 & 16,8 & 51,0 & 0,66 & 78,4 & 0,08 & 100,0 \\
\hline 13 & Y2.14 & ML & 6,6 & 1,4 & 100 & 0,0 & 10,51 & 48,0 & 6,0 & 46,0 & 16,1 & 45,0 & 0,59 & 59,0 & 0,06 & 50,0 \\
\hline 14 & $\mathrm{P} 2.10$ & LL & 5,8 & 13,4 & 90 & $-10,0$ & 10,50 & 47,8 & 6,2 & 51,0 & 16,8 & 51,0 & 1,13 & 205,0 & 0,09 & 125,0 \\
\hline 15 & $\mathrm{P} 2.14$ & LL & 5,8 & 13,4 & 100 & 0,0 & 10,50 & 47,8 & 7,1 & 73,0 & 17,3 & 56,0 & 0,71 & 92,0 & 0,07 & 75,0 \\
\hline 16 & $\mathrm{P} 1.10$ & LL & 6,5 & 2,9 & 100 & 0,0 & 10,50 & 47,8 & 6,4 & 56,0 & 17,3 & 56,0 & 0,57 & 54,0 & 0,08 & 100,0 \\
\hline 17 & Y2.7 & ML & 6,5 & 2,9 & 100 & 0,0 & 10,40 & 46,4 & 6,2 & 51,0 & 17,1 & 54,0 & 0,65 & 77,0 & 0,06 & 50,0 \\
\hline 18 & P2.1 & HL & 6,3 & 5,9 & 100 & 0,0 & 10,30 & 45,1 & 6,5 & 58,0 & 17,5 & 58,0 & 0.79 & 113,5 & 0,09 & 125,0 \\
\hline 19 & B1.7 & HL & 6,5 & 2,9 & 100 & 0,0 & 10,30 & 45,1 & 6,7 & 63,0 & 16,9 & 52,0 & 0,79 & 113,5 & 0,10 & 150,0 \\
\hline 20 & Kntrl & & 6,7 & & 100 & & 7,10 & & 4,1 & & 11,1 & & 0,37 & & 0,04 & \\
\hline
\end{tabular}

Note $: \mathrm{LL}=$ Low land, $\mathrm{ML}=$ Medium land, $\mathrm{HL}=$ High land

Selected P2.11 isolate could promote the growth of seedlings. It accelerated germination 5.1 days after planting (dap) $(23.9 \%)$ compared to control (6.7 daps), the percentage of seedling height increase was67.6\%, the leaf number was $92 \%$, and the root length was $95 \%$. Rhizobacterial isolate Y1.15 could increase the percentage of the wet weight of seedlings by 
$226 \%$ and dry weight of seedlings by $225 \%$ compared to controls. It is assumed that rhizobacterial isolates P2.11 and Y1.15 better increase the growth of chili seedlings and could better adapt to the experimental location compared to other isolates. [14]arguesthat antagonistic microbial ability is often different in increasing plant growth in areas due to complex circumstances.

Increased growth of chili seedlings applied with indigenous rhizobacterial, is assumed to have the ability to increase the plant growth known as Plant Growth Promoting Rhizobacteria (PGPR). The mechanism of plant growth-promoting is one of the added value of the application of biocontrol agent either bacterial or fungi group. PGPR is reported to stimulate plant growth. The results of [15]which treated chili seedlings with PGPR isolate Neist-2 to increase their growth at the age of 4 weeks old, i.e. seedlings height $9,25 \mathrm{~cm}$, root length $15,25 \mathrm{~cm}$, which is significantly different from the control (seedlings height $5,25 \mathrm{~cm}$ and root length $8,25 \mathrm{~cm}$ ). [16] reported the effects of 3 types of PGPR (B. pumilus, B. licheniformis, and P.fluorescens) on chili and tomato seedlings germinated in sterile and nonsterile conditions. All PGPRs were able to increase the height of seedlings and the number of leaves in sterile and nonsterile conditions, and there was no difference between sterile and nonsterile conditions. This was due to the competition between microorganisms as rhizobacteria inoculation and the effects of auxin growth hormone produced by plant roots.

\subsection{Incubation period}

All indigenous rhizobacterial isolates were able to prolong the incubation period of $C$. gloeosporioidesby 11.1-39.8\% compared to control (Table 2), and chili plants introduced with isolates B1.37 and P1.31 showed no symptoms of anthracnose disease until the age of 9 days after inoculation (dai). In primary infection, almost all indigenous RB isolates were able to decrease the intensity of $C$. gloeosporioides on chili from $80 \%$ (control) to $0-75 \%$ and simultaneously to increase chili's resistance from highly susceptible on control to susceptible highly resistant. In fact, 2 isolates of RB (B1.37 and P1.31) showed no symptoms at all or the attack intensity of $C$. gloeosporioideswas $0 \%$ and was categorized as highly resistant.

The incubation period of $C$. gloeosporioides in primary infection was generally longer in chili crops introduced with indigenous RB isolates, especially 2 isolates (B1.37 and P1.31). Introduction of indigenous rhizobacterial isolates on chili seedlings decreased the primary attack intensity of $C$. gloesporioides to 9 days since 2 isolates (B1.37 and P1.31) showed no symptoms at all or attack intensity of $C$. Gloeosporioides was $0 \%$ and it was categorized as highly resistant. This was caused by isolates B1.37 and P1.31 had plant resistance inducer indicators

Table 2. Development of anthracnose disease in chili plants introduced with indigenous rhizobacterial isolates (primary infection 9 days after inoculation)

\begin{tabular}{|c|c|c|c|c|c|c|c|}
\hline \multirow[b]{2}{*}{ No } & \multicolumn{2}{|c|}{ Isolates } & \multicolumn{2}{|c|}{ Incubation period } & \multicolumn{3}{|c|}{ Disease Intensityandcategory } \\
\hline & Code & Altitute & Day & Effectiveness & $\begin{array}{c}\text { Intensity } \\
(\%)\end{array}$ & Effectiveness & Category \\
\hline 1 & B1.37 & HL & $\sim$ & $\sim$ & 0.0 & 100.0 & Heigly resistant \\
\hline 2 & $\mathrm{P} 1.31$ & LL & $\sim$ & $\sim$ & 0.0 & 100.0 & Heigly resistant \\
\hline 4 & B2.9 & HL & 4.7 & 30.6 & 20.0 & 75.0 & Resistant \\
\hline 3 & $\mathrm{~B} 2,20$ & HL & 4.6 & 27.8 & 23.3 & 70.8 & Moderate resistant \\
\hline 5 & $\mathrm{P} 2.1$ & LL & 5.0 & 39.8 & 26.6 & 66.8 & Moderate resistant \\
\hline
\end{tabular}




\begin{tabular}{|c|c|c|c|c|c|c|c|}
\hline 6 & P2.3 & $\mathrm{LL}$ & 4.7 & 30.6 & 26.6 & 66.8 & Moderate resistant \\
\hline 7 & $\mathrm{P} 2.14$ & LL & 4.7 & 30.6 & 30.1 & 62.3 & Moderate resistant \\
\hline 8 & $\mathrm{P} 2.11$ & LL & 4.8 & 33.3 & 32.5 & 59.3 & Moderate resistant \\
\hline 9 & $\mathrm{~B} 2.11$ & $\mathrm{HL}$ & 5.1 & 32.7 & 32.5 & 59.3 & Moderate resistant \\
\hline 10 & Y2.7 & ML & 4.5 & 25.0 & 35.0 & 56.3 & Moderate resistant \\
\hline 11 & Y2.1 & ML & 4.5 & 25.0 & 38.0 & 52.5 & Moderate resistant \\
\hline 12 & B1.7 & HL & 4.6 & 27.8 & 40.0 & 50.0 & Moderate resistant \\
\hline 13 & $\mathrm{P} 2.10$ & LL & 4.3 & 19.4 & 40.0 & 50.0 & Moderate resistant \\
\hline 14 & P1.5 & LL & 4.3 & 19.4 & 43.5 & 45.6 & Moderate Susceptible \\
\hline 15 & Y1.15 & ML & 4.6 & 27.8 & 43.6 & 45.6 & Moderate Susceptible \\
\hline 16 & Y1.6 & ML & 4.3 & 19.4 & 45.0 & 43.8 & Moderate Susceptible \\
\hline 17 & B1.18 & HL & 4.5 & 25.0 & 45.0 & 43.8 & Moderate Susceptible \\
\hline 18 & Y2.14 & ML & 4.3 & 19.4 & 47.6 & 40.5 & Moderate Susceptible \\
\hline 19 & $\mathrm{Y} 2.4 \mathrm{a}$ & ML & 4.1 & 13.4 & 50.0 & 37.5 & Susceptible \\
\hline 20 & $\mathrm{~B} 2.25$ & HL & 4.3 & 19.4 & 60.0 & 25.0 & Susceptible \\
\hline 21 & $\mathrm{P} 1.10$ & LL & 4.0 & 11.1 & 65.0 & 18.8 & Susceptible \\
\hline 22 & Y1.21 & $\mathrm{ML}$ & 4.5 & 25.0 & 75.0 & 6.3 & Heigly susceptible \\
\hline 23 & B1.29 & $\mathrm{HL}$ & 3.6 & 0 & 97.0 & $-21,3$ & Heigly susceptible \\
\hline 24 & Control + & & 3.6 & & 80.0 & & \\
\hline
\end{tabular}

Note : HL=Highland, $\mathrm{ML}=$ Mediumland, $\mathrm{LL}=$ Lowland. =No symptom until 9 days after inoculation

such as: increase enzyme activity of aminloase penilalanase, peroxidase, polyphenol oxidase, phytoalexin production, antimicrobial, besides having biocontrol mechanism (production of salicylic acid), chitinase enzyme production, and PGPR mechanism (IAA growth hormone production, and phosphate solvent).Similar results were reported by [4] who indicated that 13 isolates of indigenous rizobacteria from different altitudes (Medium land : Solok District; and highlands: Agam District) could increase the resistance of chilli plants to bacterial wilt disease $R$. solanacearumup to $33,3 \%$. Furthermore, [17] reported that the antagonistic test of rhizobacteia to Fusarium oxysporum f.sp.lycopersici effectively controlled Fusarium wilt disease to $31 \%$. The results [10] the treatment of the seed with co-inoculation of the pathogen with Bacillus sp. culture showed a $65 \%$ reduction in disease incidence by the treatment as compares to the seed treated with pathogen alone $(77,5 \%)$. Furthermore, the appearance of anthracnose attack on chili with and without the introduction of rhizobacterial isolate is shown in Figure 1. 


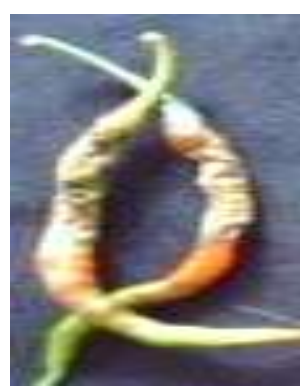

A

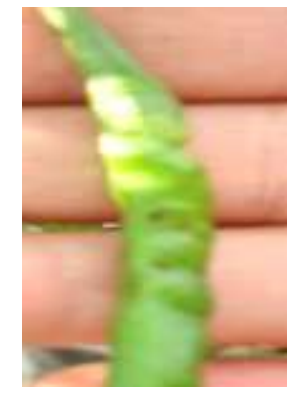

B2

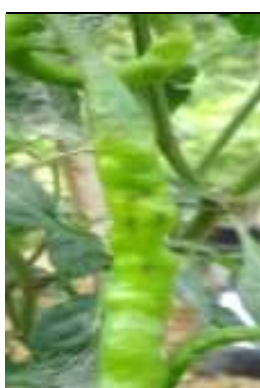

B1

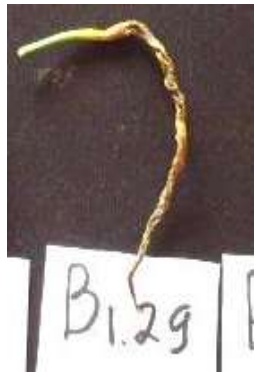

$\mathrm{C}$

Figure 1. Comparison of primary attack symptoms of C. gloeosporiodes on chili introduced with rhizobacterial isolates. A. Without the introduction of rhizobacterial isolates. B1.

Introduction with indigenous rhizobacterial isolates B1.37 and B.2. P1.31. C. Symptoms of anthracnose disease in chili plants introduced with isolate B1.29.

\subsection{The results of chili introduced with indigenous rhizobacterial isolates in secondary infection of Colletotrichum gloeosporioides}

The introduction of indigenous rhizobacterial isolates on chili seeds decreased the number of fruits $(2.1-27.4 \%)$ and the weight of the fruits (2-35.4\%) (Table 3). The introduction of chili with indigenous rhizobacterial isolates B2.11 could decrease the number and weight of diseased chili fruits to a lower point of 5.7 fruits(2.1\%) and 4.3 grams (2.0\%), and these were not significantly different from the chilies introduced with indigenous rhizobacterial isolate B1.37 that were 4.8 fruits $(2.2 \%)$ and 4.1 grams $(2.0 \%)$. Chilies introduced with indigenous rhizobacterial isolatesY1.21 showed the highest decrease in the number and weight of diseased chili fruits, i.e 50.2 fruits $(27.4 \%)$ and 46.3 grams (29.1\%).

This study showed that the introduction of chilli seeds with indigenous rhizobacterial isolates B2.11 against $C$. gloeosporioides attack resulted in the percentage of primary infection and the intensity of attack $50 \%$ and $32.5 \%$ (moderate resistant), and introduction of indigenous rhizobacterial isolate B2.9 resulted in primary infection and attack intensity respectively $20 \%$ and $20 \%$ (resistant) (Table 2). 
Table 3. Decrease of chili production due to secondary infection of Colletotrichum gloeosporioidesas a cause of anthracnose disease in chilli crops

\begin{tabular}{|c|c|c|c|c|c|c|c|c|c|c|c|c|c|c|c|}
\hline \multirow[t]{2}{*}{ No } & \multicolumn{2}{|c|}{ Isolat } & \multicolumn{6}{|c|}{ Number fruits } & \multicolumn{7}{|c|}{ Fruits Weight } \\
\hline & Code & $\begin{array}{l}\text { Altitut } \\
\mathrm{e}\end{array}$ & Total & Sick & Healthy & & Eftv & $\%$ & Total & & Sick & Healthy & & Eftv & $\%$ \\
\hline 1 & B2.11 & HL & 232,3 a & 5,7 & $226,6 a$ & & 381,1 & 2,1 & $217,7 \mathrm{a}$ & & 4,3 & $213,4 a$ & & $\begin{array}{r}507, \\
9\end{array}$ & 2,0 \\
\hline 2 & B1.37 & HL & 230,2 a & 4,8 & $225,4 a$ & & 378,5 & 2,2 & $213,4 \mathrm{a}$ & & 4.1 & $209,3 \mathrm{a}$ & & $\begin{array}{r}496, \\
2\end{array}$ & 2,0 \\
\hline 3 & $\mathrm{P} 1.31$ & LL & $221,3 \quad b$ & 5,4 & $215,9 \mathrm{~b}$ & & 358,4 & 2,4 & $202,5 \mathrm{~b}$ & & 4,6 & $197,9 \mathrm{~b}$ & & $\begin{array}{r}463, \\
8\end{array}$ & 2,8 \\
\hline 4 & P2.3 & $\mathrm{LL}$ & $207,8 \quad \mathrm{c}$ & 7,1 & $200,7 \mathrm{c}$ & & 326,1 & 3,4 & $202.6 \mathrm{~b}$ & & 6,7 & $195,9 \mathrm{~b}$ & & $\begin{array}{r}458, \\
1\end{array}$ & 3,3 \\
\hline 5 & $\mathrm{P} 2.14$ & LL & $192,1 \mathrm{~d}$ & 9,0 & $183,1 \mathrm{~d}$ & & 288,7 & 4,7 & $170,0 \mathrm{c}$ & & 8,0 & $162,0 \mathrm{c}$ & & $\begin{array}{r}361, \\
5\end{array}$ & 4,7 \\
\hline 6 & $\mathrm{P} 2.1$ & LL & 181,3 efg & 21,1 & $160,2 \mathrm{e}$ & & 240,1 & 11,6 & $172.2 \mathrm{c}$ & & 14,2 & $158,0 \mathrm{c}$ & & $\begin{array}{r}350, \\
1\end{array}$ & 8,2 \\
\hline 7 & $\mathrm{P} 2.10$ & LL & $184,4 \mathrm{de}$ & 35,9 & $148,5 \mathrm{f}$ & & 215,3 & 19,5 & $178.1 \mathrm{c}$ & & 35,5 & $142,6 \mathrm{~d}$ & & $\begin{array}{r}306, \\
2\end{array}$ & 19,9 \\
\hline 8 & B2.25 & $\mathrm{HL}$ & 180,0 efg & 33,5 & $146,5 \mathrm{fg}$ & & 211,0 & 18,6 & $163.3 \mathrm{~d}$ & & 28,0 & 135,3 & & $\begin{array}{r}285 \\
4\end{array}$ & 17,1 \\
\hline 9 & $\mathrm{P} 2.11$ & LL & $174,5 \quad \mathrm{~g}$ & 33,6 & $140,9 \mathrm{fg}$ & & 199,2 & 19,3 & $167.1 \mathrm{~d}$ & & 33,7 & 133,4 & & $\begin{array}{r}280 \\
0\end{array}$ & 20,2 \\
\hline 10 & B2.20 & HL & 180,6 efg & 40,7 & $139,9 \mathrm{fg}$ & & 138,4 & 22,6 & 157.3 ef & & 24,6 & 132,7 & & $\begin{array}{r}249 \\
5\end{array}$ & 22,0 \\
\hline 1 & P1.5 & LL & 183,3 efg & 44,4 & $139,4 \mathrm{fg}$ & & 132,9 & 24,9 & $\begin{array}{l}163.5 \\
\text { defg }\end{array}$ & & 40.8 & 122,7 & & $\begin{array}{r}247, \\
5\end{array}$ & 25,4 \\
\hline 12 & Y2.1 & ML & $179,5 \quad \mathrm{fg}$ & 45,6 & 133,9 & $\mathrm{j}$ & 138,9 & 26,0 & $164.5 \mathrm{de}$ & & 42,5 & 122,0 & $f$ & $\begin{array}{r}220 \\
7\end{array}$ & 13,3 \\
\hline 13 & Y1.21 & ML & 183,5 ef & 50,2 & 133,3 & $\mathrm{j}$ & 132,3 & 27,4 & 158.9 ef & & 46,3 & $112,6 \mathrm{~g}$ & & $\begin{array}{r}220 \\
7 \\
\end{array}$ & 29,1 \\
\hline 4 & $\begin{array}{l}\text { Y1.15 } \\
\mathrm{k}\end{array}$ & ML & 183,5 ef & 35,2 & $148,3 \mathrm{f}$ & & 147,3 & 19,2 & 148.7 & $\mathrm{~g}$ & 36,8 & 111,9 & $\mathrm{~g}$ & $\begin{array}{r}218 \\
8 \\
\end{array}$ & 25,2 \\
\hline 15 & B1.18 & HL & 178,3 efg & 42,9 & 135,4 & $\mathrm{j}$ & 134,4 & 13,5 & 146.3 & $\mathrm{~g}$ & 37,6 & 108,7 & $\mathrm{~g}$ & $\begin{array}{r}209 \\
6 \\
\end{array}$ & 27,9 \\
\hline 16 & B2.9 & $\mathrm{HL}$ & 174,9 & 42,5 & $132,4 \mathrm{fg}$ & & 131,4 & 10,6 & 149.3 & $\mathrm{~g}$ & 42,1 & 107,2 & $\mathrm{~g}$ & $\begin{array}{r}205 \\
4 \\
\end{array}$ & 32,7 \\
\hline 17 & B1.7 & $\mathrm{HL}$ & $162,7 \quad h$ & 36,5 & 126,21 & $\mathrm{kl}$ & 125,2 & 13,7 & 138.2 & $\mathrm{~h}$ & 31,1 & 107,1 & $\mathrm{~g}$ & $\begin{array}{r}205 \\
1 \\
\end{array}$ & 22,5 \\
\hline 18 & B1.29 & $\mathrm{HL}$ & 160,2 & 39,1 & 121,1 & 1 & 120,1 & 15,2 & 146.3 & $\mathrm{~g}$ & 40,0 & 106,3 & $\mathrm{~g}$ & $\begin{array}{r}202, \\
8\end{array}$ & 27,3 \\
\hline 19 & P1.10 & LL & 159,8 & 48,6 & 111,2 & $\mathrm{~m}$ & 110,2 & 19,0 & 142.3 & $\mathrm{~g}$ & 44,4 & 97,9 & $\mathrm{~h}$ & $\begin{array}{r}178, \\
9\end{array}$ & 31,2 \\
\hline 20 & Y1.6 & ML & 151,2 & 39,8 & 111,4 & $\mathrm{~m}$ & 110,4 & 17,4 & 137.8 & $\mathrm{~h}$ & 42,2 & 95,6 & $\mathrm{~h}$ & $\begin{array}{r}172, \\
3 \\
\end{array}$ & 30,6 \\
\hline 21 & $\mathrm{Y} 2.4 \mathrm{a}$ & ML & 149,7 & 48,8 & 100,9 & $\mathrm{n}$ & 99,9 & 21,8 & 133.6 & $\mathrm{~h}$ & 46,4 & 87,2 & $\mathrm{i}$ & $\begin{array}{r}148 \\
4 \\
\end{array}$ & 34,7 \\
\hline 22 & Y2.14 & ML & 145,5 & 46,8 & 98,7 & $\mathrm{n}$ & 97,7 & 22,1 & 130.6 & $\mathrm{~h}$ & 46,3 & 84,3 & $\overline{\mathrm{i}}$ & $\begin{array}{r}140, \\
1 \\
\end{array}$ & 35,4 \\
\hline 23 & Y2.7 & ML & 136,5 & 36,2 & 100,4 & $\mathrm{n}$ & 99,4 & 19,4 & 118.7 & $\mathrm{i}$ & 35,0 & 83,7 & $\mathrm{i}$ & $\begin{array}{r}138 \\
4 \\
\end{array}$ & 29,5 \\
\hline
\end{tabular}




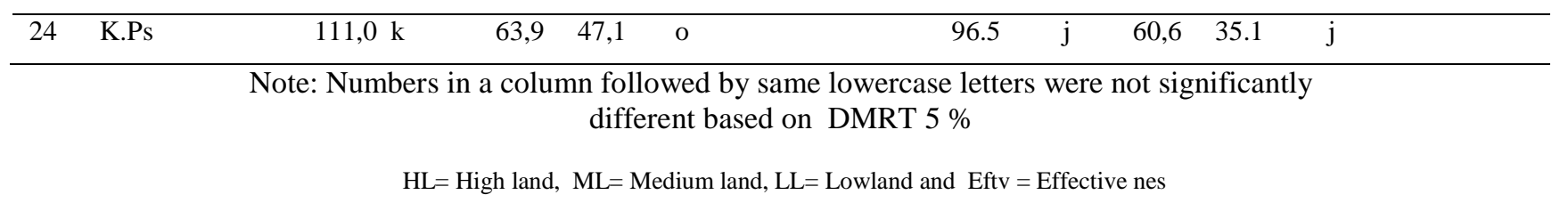

Furthermore, the introduction of isolating B2.11 at the age of 5 weeks after inoculation was able to decrease the percentage of secondary infection, $4.3 \%$, and decrease the number of diseased chili fruits to 4.3. While chili seeds introduced with rhizobacterial isolates B2.9 resulted in a greater percentage of secondary infection, 34\%, and the decreasing number of fruits $10.6 \%$, and the weight of fruits with the disease to $327 \%$. According to [18], $C$. gloeosporioides is a weak parasite that infects chili fruits through injury, so that in a secondary attack, chili is able to avoid C.gloeosporioides attack. This is possible because there is an accumulation of metabolites in chili plants due to microbial introduction or because of the physical barrier that limits the growth and distribution of pathogens. This is in contrast with the results of research by [13]that indicates that a high incidence of $C$. gloeosporioides on chili crops as a cause of anthracnose disease is based on the intensity of primary infection attacks.

\subsection{Growth and yield of chili}

(1) Plant height (cm).The introduction of indigenous rhizobacterial isolate in chili seeds could increase the plant height from 27.3 to $35.6 \mathrm{~cm}$. IsolateB 1.37 was able to increase the height of chili plantsby35.6 cm, which is not significantly different from B2.11 and P1.31, but significantly different from other treatments. The effectiveness of chili plant height increase after the introduction of the indigenous rhizobacterial isolate was 0.4 to $30 \%$. This is due to the fact that rhizobacterial isolates are capable of producing IAA growth hormones to stimulate plant growth. The results of Klement [12] and Gowtham[18] indicated that rhizobacterial isolates strain Bacillus spp had the ability to increase the height of chili plants $37,40 . \mathrm{cm}$ compared to control $(36,34 \mathrm{~cm})$. Saleem [4] found that inoculation Sunflower with 3 PGPR.

According to Semangun [19], several types of bacteria as biological agents have multifunctions: producing antibiotics and chitinase enzyme, capable of competing, increasing nutrient availability for plants, promoting plant growth, and inducing plant resistance.

(2). Results of chili plants. All the indigenous rhizobacterial isolates introduced in chili seeds were able to increase the yield of chili crops from 99.1 to $491.5 \%$ compared to controls. The introduction of indigenous rhizobacterial isolateB2.11was the best method in increasing chilli crop yield by 213.4 gram/crop, which was equivalent to 6.92 ton/ha and not significantly different from the introduction of indigenous rhizobacterial isolate, B1.37, with the result of 209.3 gram/crop, which was equivalent to 6.71 tons/ha. The treatment that resulted in the lowest yield was positive control with a yield of 35.1 grams/plant, which was equivalent to 1.17 tons/ha (Table 4). Chili seeds introduced with indigenous rhizobacterial isolates, B2.11, had the highest amount of crops which resulted in the highest yield of chili crops. In addition, the introduction of indigenous rhizobacterial isolate, B2.11can improve the status of chili's resistance due to anthracnose disease caused by $C$. gloeosporioides. The severity of primary infection was $50 \%$, and the disease severity of secondary infection was $4.3 \%$. There was a decrease in attack percentage from primary infection to a secondary infection that could be caused by a smaller number and weight of chili fruits with the disease. On the other hand, the number and weight 
of healthy chili fruits increased . Furthermore [12] showed that the application of rhizobacterial strain Bacillus spp in chili seeds was able to increase the weight crop yield by 223,33 gram/crop compared to control (65,0 gram/crop). The result of Baker [20] reported that Pseudomonas flurescens strain WCS374 on radish crop could increase radish yield by $40 \%$, and to suppress Fusarium wilt diseases. [17] reported that introduction rhizobacteria isolate Bacillus amyloliquefacien CS1 showed significantly higher fungal growth inhibition of $31 \%$, followed by Bacillus amyloliquefacien PCfs (28\%) toward Fusarium wilt deaseas in tomato. This was caused isolate Bacillus amyloliquefacien CS1 and Bacillus amyloliquefacien PCfshaving biocontrol mechanism (production Hydrogen cyanide, antifungal secondary metabolister), production of enzymes aminocyclopropane carboxylic acid, chitinase and cellulase and PGPR mechanism (IAA growth hormone production, and phosphate solvent).

Table 4. Results of chili crops introduced with indigenous rhizobacteria isolate against

$$
\text { C.gloeosporioides }
$$

\begin{tabular}{|c|c|c|c|c|c|c|c|c|c|}
\hline \multirow[b]{2}{*}{ No } & \multicolumn{2}{|c|}{ Isolat } & \multicolumn{3}{|c|}{ Number healthy fruits } & \multicolumn{4}{|c|}{ Chili Production } \\
\hline & Code & Altitute & & Fruit & $\begin{array}{l}\text { Eftv } \\
(\%)\end{array}$ & $\begin{array}{r}\text { Fre } \\
\text { weig }\end{array}$ & $\begin{array}{l}\text { sh fruits } \\
\text { ht (gram) }\end{array}$ & Tons/ha & $\begin{array}{l}\text { Eftv } \\
(\%)\end{array}$ \\
\hline 1 & B2.11 & HL & 226,6 & $\mathrm{a}$ & 378,5 & 213,4 & $\mathrm{a}$ & 6,92 & 491,5 \\
\hline 2 & B1.37 & HL & 225,4 & $\mathrm{a}$ & 362,0 & 209,3 & $\mathrm{a}$ & 6,71 & 473,5 \\
\hline 3 & $\mathrm{P} 1.31$ & LL & 215,9 & $\mathrm{~b}$ & 358,3 & 197,6 & $\mathrm{~b}$ & 6,33 & 441,0 \\
\hline 4 & $\mathrm{P} 2.3$ & LL & 200,7 & c & 326,1 & 195,9 & $\mathrm{~b}$ & 6,29 & 437,6 \\
\hline 5 & $\mathrm{P} 2.14$ & $\mathrm{LL}$ & 183,1 & d & 288,7 & 162,2 & $\mathrm{c}$ & 5,20 & 329,9 \\
\hline 6 & $\mathrm{P} 2.1$ & LL & 160,2 & $\mathrm{e}$ & 240,1 & 158,0 & $\mathrm{c}$ & 5,03 & 329,9 \\
\hline 7 & $\mathrm{P} 2.10$ & LL & 148,5 & $\mathrm{f}$ & 215,2 & 142,6 & $\mathrm{~d}$ & 3,82 & 226,5 \\
\hline 8 & B2.25 & $\overline{\mathrm{HL}}$ & 146,5 & $\mathrm{fg}$ & 211,0 & 135,3 & $\mathrm{e}$ & 3,98 & 240,2 \\
\hline 9 & P2.11 & LL & 140,9 & fghi & 199,2 & 133,4 & $\mathrm{e}$ & 3,68 & 214,5 \\
\hline 10 & Y2.1 & ML & 139,9 & fghi & 197,0 & 132,7 & $\mathrm{e}$ & 3,06 & 161,5 \\
\hline 11 & B2.20 & HL & 139,2 & fghi & 195,5 & 122,7 & $\mathrm{f}$ & 3,52 & 200,9 \\
\hline 12 & P1.5 & LL & 133,9 & ijk & 184,2 & 122,0 & $\mathrm{f}$ & 3,17 & 170,9 \\
\hline 13 & Y 1.21 & ML & 133,3 & $\mathrm{ijk}$ & 183,0 & 112,6 & $\mathrm{~g}$ & 2,83 & 141,8 \\
\hline 14 & Y1.15 & ML & 148,3 & $\mathrm{f}$ & 214,8 & 111,9 & $\mathrm{~g}$ & 3,12 & 195,0 \\
\hline 15 & B1.18 & HL & 135,4 & hij & 187,5 & 108,7 & g & 3,03 & 159,0 \\
\hline 16 & B2.9 & HL & 142,4 & fgh & 202,3 & 107,2 & $\mathrm{~g}$ & 3,57 & 205,1 \\
\hline 17 & B1.7 & HL & 126,2 & $\mathrm{kl}$ & 167,9 & 107,1 & $\mathrm{~g}$ & 3,13 & 167,5 \\
\hline 18 & B1.29 & HL & 121,1 & 1 & 157,1 & 106,3 & $\mathrm{~g}$ & 2,92 & 149,6 \\
\hline 19 & P1.10 & LL & 111,2 & $\mathrm{~m}$ & 136,1 & 97,9 & $\mathrm{~h}$ & 2,63 & 124,8 \\
\hline 20 & Y1.6 & ML & 111,4 & $\mathrm{~m}$ & 136,5 & 95,6 & $\mathrm{~h}$ & 2,98 & 154,7 \\
\hline 21 & $\mathrm{Y} 2.4 \mathrm{a}$ & $\mathrm{ML}$ & 100,9 & $\mathrm{n}$ & 114,2 & 87,2 & $\mathrm{i}$ & 2,39 & 104,3 \\
\hline 22 & $\mathrm{Y} 2.14$ & ML & 98,7 & $\mathrm{n}$ & 109,6 & 84,3 & $\mathrm{i}$ & 2,33 & 99,1 \\
\hline 23 & Y2.7 & DS & 100,4 & o & 113,2 & 83,7 & $\mathrm{i}$ & 2,57 & 119,7 \\
\hline 24 & K.Pos & & 47,1 & $\mathrm{p}$ & & $35.1 \mathrm{j}$ & & 1,17 & \\
\hline
\end{tabular}

Note : Numbers in column followed by same lowercase letters were not significantly different based on DMRT $5 \%$

$\mathrm{LL}=$ Low land, $\mathrm{ML}=$ Medium land, $\mathrm{HL}=$ High land, $\mathrm{Eftv}=$ Effective ness 
According to Prasath [21], the anthracnose-resistant chili genotype has high phenol content and active enzymes (ortho dihydroxy phenol, peroxidase, polyphenol oxidase, and phenylalanine ammonia-lyase) compared to non-resistant chili genotypes. So the reaction between the phenol content in different genotypes with the fungus Colletotrichum spp.will produce different effects that are reflected in the intensity of the attack.

\section{Conclusions}

Isolates B1.37 obtained from highlands and P1.31 obtained from lowland were able to control Colletotrichum gloeosporioides with an intensity attack of0 \% through resistance induction mechanism. Isolates P2.11 was able to promote the growth of chili seedlings on the parameters time is taken to germinate, seedling height, number of leaves and roots length of chili seedlings, while introduction with isolates Y1.15.k resulted in high increase of wet and dry chili seedlings. Isolates B2.11 caused the higher yield of chili cropsby 213.4 gram/crop equivalent to 6.92 tons/ha which is not significantly different from the introduction with isolate B1.37 that yielded209.3 gram/crops equivalent to 6.71 tons/ha.

\section{Acknowledgment}

I would like to thank my advisors for improving this paper for publication in the International Journal on WMA 2018.

\section{References}

[1] P. P. Than, H. Prihastuti, S. Phoulivong, P. W. J. Taylor, and K. D. Hyde, "Chilli anthracnose disease caused by Colletotrichum species," J. Zhejiang Univ. Sci. B, vol. 9, no. 10 , p. $764,2008$.

[2] S. C. Nayaka, A. C. U. Shankar, S. R. Niranjana, H. S. Prakash, and C. N. Mortensen, "Anthracnose disease of chilli pepper," Tech. Bull. Publ. by Asian Seed Heal. Cent. Karnataka, India Danish Seed Heal. Cent. Dev. Countries, Denmark, vol. 14, 2009.

[3] H. Chauhan, D. J. Bagyaraj, G. Selvakumar, and S. P. Sundaram, "Novel plant growth promoting rhizobacteria-Prospects and potential,” Appl. Soil Ecol., vol. 95, pp. 38-53, 2015.

[4] M. Saleem, H. N. Asghar, Z. A. Zahir, and M. Shahid, "Impact of lead tolerant plant growth promoting rhizobacteria on growth, physiology, antioxidant activities, yield and lead content in sunflower in lead contaminated soil," Chemosphere, vol. 195, pp. 606614, 2018.

[5] Y. Yanti, "Peroxidase enzyme activity of rhizobacteria-introduced shallots bulbs to induce resistance of shallot towards bacterial leaf blight (Xanthomonas axonopodis pv allii)," Procedia Chem., vol. 14, pp. 501-507, 2015.

[6] T. Habazar, Y. Yanti, and C. R. Nasution, "Screening of Rhizobacterial Indigenous as Biocontrol Agents Against Bacterial Wilt on Chili Using In Planta Technique," in Proceeding of the 1st International Conference on Tropical Agriculture, 2017, pp. 295308.

[7] Fatimah, "Characterization of resistance mechanisms of chilli induced by the introduction of indigeous rhizobacterial towards anthracnose (Colletotrichum gloesporioides)," Andalas University, 2016.

[8] R. J. Cook and K. F. Baker, The nature and practice of biological control of plant 
pathogens. American Phytopathological Society, 1983.

[9] Y. Yanti, T. Habazar, R. Reflinaldon, C. R. Nasution, and S. Felia, "Indigenous Bacillus spp. ability to growth promoting activities and control bacterial wilt disease (Ralstonia solanacearum)," Biodiversitas J. Biol. Divers., vol. 18, no. 4, pp. 1562-1567, 2017.

[10] S. Živković, S. Stojanović, Ž. Ivanović, V. Gavrilović, T. Popović, and J. Balaž, "Screening of antagonistic activity of microorganisms against Colletotrichum acutatum and Colletotrichum gloeosporioides," Arch. Biol. Sci., vol. 62, no. 3, pp. 611-623, 2010.

[11] N. Ashwini and S. Srividya, "Potentiality of Bacillus subtilis as biocontrol agent for management of anthracnose disease of chilli caused by Colletotrichum gloeosporioides OGC1," 3 Biotech, vol. 4, no. 2, pp. 127-136, 2014.

[12] and D. C. S. Klement.Z., K. Rodolph., "Methodsin Phytobacteriology," Academia.Kiado, 1990.

[13] M. Datta, R. Palit, C. Sengupta, M. K. Pandit, and S. Banerjee, "Plant Growth Promoting Rhizobacterial Enhance Growth And Yield Of Chilli (Capsicum Annum L.) Under Field Condition," Aust. J. Crop Sci., vol. 5, 2011.

[14] G. . Paul et al., "Development of anthracnose resistant chili pepper varietas at AVRDC.," 2008.

[15] G. Gupta, S. S. Parihar, N. K. Ahirwar, S. K. Snehi, and V. Singh, "Plant growth promoting rhizobacteria (PGPR): current and future prospects for development of sustainable agriculture," J Microb Biochem Technol, vol. 7, no. 2, pp. 96-102, 2015.

[16] K. S. Jadon, R. Shah, H. N. Gour, and P. Sharma, "Management of blight of bell pepper (Capsicum annuum var. grossum) caused by Drechslera bicolor," brazilian J. Microbiol., vol. 47, no. 4, pp. 1020-1029, 2016.

[17] J. A. L. García, A. Probanza, B. Ramos, and F. J. G. Mañero, "Effects of three plant growth-promoting rhizobacteria on the growth of seedlings of tomato and pepper in two different sterilized and nonsterilized peats," Arch. Agron. Soil Sci., vol. 49, no. 1, pp. 119-127, 2003.

[18] S. R. N. Gowtham, H.G., P.hariprasad., S.C. Nayak., "Application of rhizobacteria antagonistic to Fusarium oxysporum f.sp.lycopersici for the management of Fusarium wilt in tomato," 2016.

[19] H. Semangun, "Diseses of horticulture plants in Indonesia," Gajah Mada University Press, 2000.

[20] P. A. H. M. Bakker, C. M. J. Pieterse, and L. C. Van Loon, "Induced systemic resistance by fluorescent Pseudomonas spp.," Phytopathology, vol. 97, no. 2, pp. 239-243, 2007.

[21] D. Prasath and V. Ponnuswami, "Screening of chilli (Capsicum annuum L.) genotypes against Colletotrichum capsici and analysis of biochemical and enzymatic activities in inducing resistance," Indian J. Genet. Plant Breed., vol. 68, no. 3, pp. 344-346, 2008. 